Katarzyna Lisowska

Instytut Filologii Polskiej, Uniwersytet Wrocławski

\title{
Sztuka radości i praktyka anarchii. O powieści Goliardy Sapienzy i kilku polskich utworach
}

Sztuka radości to powieść, którą Goliarda Sapienza (1924-1996) [Bazzoni 2018: 1, 3] pisała dziesięć lat, między 1967 a 1976 rokiem [Sapienza 2018: 593]. Niestety, mimo wielu prób, z których dokładne relacje są dołączone do polskiego wydania posłowia [Scarpa 2018: 606-621], za życia autorki udało się opublikować tylko pierwszą część utworu, co zresztą nastąpiło wiele lat po ukończeniu rękopisu, czyli w 1994 roku [Pellegrino 2018a: 11-12; Scarpa 2018: 617]. Jednak o tekście zrobiło się głośno dopiero na początku tego wieku, przede wszystkim dzięki przekładom: niemieckiemu, francuskiemu i hiszpańskiemu [Scarpa 2018: 617-620]. Polskie tłumaczenie zostało wydane w 2018 roku i jest - jak dotychczas - jedyną opublikowaną u nas książką autorki'.

Powieść przedstawia losy narratorki i zarazem bohaterki Modesty (nazywanej także Mody). Dziewczyna wywodzi się z ubogiej sycylijskiej rodziny, ale na skutek splotu okoliczności, a także swojego bezkompromisowego dążenia do niezależności, zostaje dalej. 
księżną - dziedziczką arystokratycznego rodu. Ponieważ urodziła się w 1900 roku, to na jej życiorysie nieuchronnie odcisnęły piętno burzliwe wydarzenia XX wieku [por. też Murek 2018]. Modesta jest postacią nietuzinkową i kontrowersyjną, co było zresztą jednym z powodów długiego oczekiwania na publikację powieści [zob. Pellegrino 2018a: 9; 2018b: 642]. Sama autorka również była bardzo wyrazistą osobistością kultury włoskiej ubiegłego stulecia. Zanim poświęciła się pisarstwu, zajmowała się aktorstwem teatralnym i filmowym. Całe życie obracała się w kręgach radykalnej lewicy, do której należeli też jej rodzice: Maria Guidice i Giuseppe Sapienza². Ten kontekst będzie dla mnie szczególnie istotny, ponieważ ślady wspomnianej orientacji światopoglądowej, także w wariancie anarchistycznym, można znaleźć w omawianym utworze 3 . Do tej kwestii jeszcze powrócę.

Dlaczego warto pisać o Sztuce radości i pod jakim kątem należy ją analizować? Nathalie Castagné [2019], ttumaczka tekstu na język francuski, przywołała świadectwa czytelniczek, które zmieniły życie pod wpływem powieści. Z literaturoznawczego punktu widzenia trzeba zapytać, jakie elementy tekstu składają się na siłę jego oddziaływania. Ujmując rzecz tradycyjnie, należałoby się skupić na współpracy formy i treści książki. Na pierwszej z wymienionych płaszczyzn uwagę zwraca przede wszystkim specyficzna dynamika, wynikająca m.in. z obszernych, skutecznie naśladujących nieład żywej komunikacji, zapisanych niekiedy niemal w konwencji dramatycznej dialogów [por. np. Sapienza 2018: 395-399, 426-434] $]^{4}$,

Więcej na temat biografii autorki pisali np. Angelo Pellegrino [2018a: 9-12; 2018b: 627-657], Domenico Scarpa [2018: 600-602], Alberica Bazzoni [2018: 1-5] (zwrócenie uwagi na tę ostatnią publikację zawdzięczam cytowanemu dalej artykułowi Barbary Kornackiej [2018]).

3 Jak słusznie zauważa w posłowiu do powieści Scarpa [2018: 603]: „Światopogląd, który naprawdę się w tej książce liczy i który dominuje nad jej pedagogiczną intencją, to ideologia praktyki anarchistycznej”. O tym, że przywołany nurt był bliski autorce, świadczy m.in. życzenie Sapienzy odnotowane przez Scarpę: pisarka chciała, aby na jej pogrzebie znalazły się „czerwone flagi - oraz czarne, anarchistowskie" [testament Goliardy Sapienzy, Rzym, 30 maja 1988; cyt. za: Scarpa 2018: 621; por. też Pellegrino 2018a: 640; Scarpa 2018: 603]. Więcej na temat roli anarchizmu w twórczości Sapienzy pisała Bazzoni [2018]. W omówieniu powieści Weronika Murek [2018] słusznie podkreśla, że „przez większą część książki przetaczają się dialogi, w których dość jasno, szerokim 
płynnego przechodzenia narracji z pierwszo- do trzecioosobowej ${ }^{5}$ czy czasoprzestrzennych przeskoków ${ }^{6}$. Zabiegi te skutecznie służą drugiej - treściowej - sferze powieści, i to właśnie jej chciałabym się dokładnie przyjrzeć, aby w dalszej części artykułu zestawić Sztukę radości z kilkoma polskimi tekstami pod kątem poruszanych zagadnień. Wydaje się zresztą, że problemy przedstawione w utworze przynajmniej częściowo odpowiadają za transformacyjny (i transgresyjny?) wymiar dzieła Sapienzy. Z pewnością zaś istnieje szansa, iż w kontekście polskiej kultury trafiają one w kilka czułych punktów, a więc mogą zyskać subweryswny charakter. Wywrotowość ta w pewnym stopniu zaś wynika z anarchistycznego zaplecza powieści. W dalszej części niniejszego szkicu mogłabym się zatem skupić na usytuowaniu powieści Sapienzy w kontekście roli, jaką anarchizm odegrał w rodzimej kulturze, jednak z takim założeniem wiązałoby się kilka problemów?

Po pierwsze, prawdopodobnie materiał porównawczy okazałby się skąpy, skoro o nurcie tym zwykło się mówić, że nie wywarł znaczącego wpływu na polskie życie społeczne i polityczne [por. Kamiński 2011: 296]. Nie znaczy to oczywiście, iż nie oddziałał na nie wcale - nie tylko po 1980 roku, kiedy znaczenie

gestem i bez większej szansy na dwuznaczność czy zwątpienie przedstawiane są te czy inne poglądy, myśli, uczynki i zaniedbania” [por. też Kwiecień 2018: 5-6; Serkowska 2019: 79].

5 Jak podkreśla tłumacz, Tomasz Kwiecień [2018: 5], wspomniany zabieg, polegający na tym, że postać stosuje trzecią osobę w odniesieniu do samej siebie, jest typowy dla kultury sycylijskiej [por. też Scarpa 2018: 599; Serkowska 2019: 79]. Techniką tą często posługują się np. Carmine („,- Co jest, Modesta? Co jest? Możesz mówić do Carminego" [Sapienza 2018: 228]) lub Pietro („-Do usług jaśnie wielmożnej pani, niech księżna wybaczy Pietrowi, jeśli przeszkadza” [Sapienza 2018: 317 (por. s. 5)], a także sama Modesta jako narratorka-bohaterka: „Ale nie mam sily iść. Pusta w środku Modesta patrzy na swoje odbicie w witrynie baru" [Sapienza 2018: 550; zob. też Serkowska 2019: 79].

6 Por. np. płynne „jak w kinematografie” [Sapienza 2018: 505] przejście między relacją z pobytu Modesty i jej przyjaciółki Niny w więzieniu a opowieścią o ich życiu na wyspie [Sapienza 2018: 505; zob. też Scarpa 2018: 599].

7 Inną ścieżką interpretacji byłoby wyłuskanie z powieści możliwie największej liczby anarchistycznej odniesień. Taki tryb lektury opierałby się jednak głównie na katalogowaniu wątków i chyba niewiele by wniósł do rozważań na temat (potencjalnej) recepcji książki w Polsce. 
ruchów skupionych pod tym szyldem wzrosło ${ }^{8}$, lecz także we wcześniejszych okresach ${ }^{9}$ Z punktu widzenia tego szkicu najistotniejsze byłyby oddźwięki tej perspektywy w kulturze, przede wszystkim w literaturze, choć z tą kwestią również wiązałyby się pewne trudności.

Po drugie, należałoby bowiem zapytać, o jakim właściwie anarchizmie mowa. Jest bowiem jasne, że pod tą etykietą kryje się mnóstwo zróżnicowanych koncepcji, praktyk i tradycji. Odpowiedź na to pytanie musiałaby pozostać równie wieloznaczna, ponieważ anarchistyczne wątki, które, jak się wydaje, przenikały do polskiej literatury, także były wielorakie. Nie da się zaproponować ich przeglądu, ale wystarczy zauważyć, iż nurt ten w różny sposób przenikał do twórczości literackiej, zwłaszcza na przełomie XIX i Xx wieku oraz w międzywojniu [Kamiński 2011: 301-302, 334]. Na przykład Kazimierz Wyka [2003: 115-119; por. też Kamiński 2011: 301] wskazuje na znaczenie anarchizmu w kształtowaniu się duchowości młodopolskiej ${ }^{10}$. Idee te w różny sposób oddziałały na autorów, takich jak: Stanisław Przybyszewski, Tadeusz Miciński czy Karol Irzykowski, Stefan Żeromski, Stanisław Brzozowski, Kazimierz Przerwa-Tetmajer, Andrzej Strug, czy Gustaw Daniłowski, a także, później, Emil Zegadłowicz, czy Władysław Broniewski [Wyka 2003: 115-119; Kamiński 2011: 299, 301-302, 317, 324, 334]. Wydaje się jednak, że z takiego przeglądu niewiele wynika. Jak już

8 Por. np. publikację Radosława Antonowa [2004] poświęconą historii polskiego anarchizmu po 1980 roku [zob. też Kamiński 2011: 311].

9 Por. np. przekrojowe uwagi Antoniego A. Kamińskiego [2011: 296-346] na temat polskiej recepcji myśli anarchistycznej.

Badacz (nieco upraszczająco) kojarzy wspomnianą perspektywę z wiernością „zasadom niszczycielskim” oraz nieograniczonymi wolnością i buntem [Wyka 2003: 116, 118-119]. Zasadne wydaje się stwierdzenie, że na twórczość ówczesnych pisarzy w różnym stopniu oddziaływały koncepcje Maxa Strinera, Georges’a Sorela, Élisée’a Reclusa, Pierre’a-Josepha Proudhona czy - z polskich myślicieli - Edwarda Abramowskiego, o czym pisał Kamiński [2011: 299, 301-302, 324]. Ten ostatni nie jest może teoretykiem anarchistycznym w ścisłym sensie, ale funkcjonuje niejako w orbicie tego nurtu (na temat kontrowersji dotyczących przynależności ideowej filozofa pisał Kamiński [2011: 321-322]). Podobnie rzecz ma się z Janem Wacławem Machajskim - przyjacielem Stefana Żeromskiego z czasów młodości i pierwowzorem kilku postaci literackich z jego tekstów [Kamiński 2011: 317]. 
zaznaczyłam, mówimy tu o różnych, dość wyrywkowo zrekonstruowanych anarchizmach, stanowiących przecież bardzo niejednolity zbiór. W dodatku przywołane wyżej, stosunkowo uporządkowane obserwacje dotyczą odleglejszej przeszłości, mniej zaś, jak sądzę, wiemy o późniejszych literackich oddźwiękach omawianej perspektywy w Polsce.

Po trzecie, w kontekście Sztuki radości trzeba zastanowić się nad rolą kobiet w polskim anarchizmie. O ile na płaszczyźnie społeczno-politycznej z pewnością jest do odnotowania kilka nazwisk ${ }^{11}$, o tyle w obszarze literatury sytuacja wydaje się bardziej skomplikowana. Sądzę bowiem, że dałoby się przywołać autorki, których twórczość można by usytuować w bardzo szeroko i luźno rozumianej orbicie anarchizmu, ale nie zawsze byłyby to postaci związane z tą perspektywą bezpośrednio. Warto by np. odnieść się do Marii Komornickiej / Piotra „Odmieńca” Własta i jej/jego umiłowania wolności' ${ }^{12}$ lub Marii Dąbrowskiej - zainteresowanej spółdzielczością i zafascynowanej postacią Edwarda Abramowskiego [Kamiński 2011: 323] $]^{13}$. Z nowszych utworów sensowne byłoby wymienienie współczesnych polskich powieści nawiązujących do problematyki emancypacji jednostki spod władzy opresywnych

O tym, że kobiety, często pochodzenia żydowskiego, chętnie się angażowały w początki ruchu anarchistycznego na ziemiach polskich, świadczy choćby zebrana przez Hermana Rappaporta [zebrał i oprac. 1981: 302-325] lista osób represjonowanych przed I wojną światową za tego rodzaju działalność. Choć $\mathrm{w}$ wykazie dominują mężczyźni, to znalazła się w nim również niemała grupa aktywistek. Warto także wspomnieć m.in. o dokonaniach Izabeli Zielińskiej, lekarki, jedynej przedstawicielki polskich anarchistów na kongresie w Amsterdamie w 1907 roku [Kamiński 2011: 321], a także o Marii Orsetti. Druga z kobiet jest kojarzona przede wszystkim z ruchem spółdzielczym, ale, jak wskazuje Piotr Laskowski [2019: XLIII-LII], w jej koncepcjach ujawniały się też sympatie anarchistyczne. Dokonawszy przeskoku w czasie, trzeba też zauważyć, że od początku lat 90. ubiegłego wieku znaczenie w Polsce zyskał anarchofeminizm [por. np. Antonów 2004: 284-288] - nurt, którego początki są często kojarzone z przywołaną dalej Emmą Goldman [Majewska 2014: 351; por. też Chutnik 2016]. Istotna byłaby zwłaszcza twórczość Marii Komornickiej / Piotra „Odmieńca” Własta sprzed przemiany (dziękuję Recenzentowi za zwrócenie uwagi na tę kwestię).

13 Jak przypomina Kamiński [2011: 323], Maria Dąbrowska napisała literacką biografię myśliciela: Życie i dzieło Edwarda Abramowskiego (1925). 
instytucji, jak choćby niemal klasycznej powieści Izabeli Filipiak (dziś Morskiej) Absolutna amnezja ${ }^{14}$.

Z powyższych powodów w dalszych rozważaniach nie będę się koncentrowała na dialogu, w jaki powieść Sapienzy mogłaby wejść z polskimi wariantami anarchizmu, zwłaszcza z ich realizacjami na polu kultury i literatury. Jednak duch wspomnianego ruchu będzie się unosił nad poniższymi obserwacjami. Zestawię bowiem Sztukę radości z kilkoma napisanymi przez polskie autorki utworami prozatorskimi, współdzielącymi z włoskim tekstem pewne tematy istotne z perspektywy anarchizmu, choć oczywiście do niego nieograniczone. Z jednej strony nie chcę zamykać powieści Sapienzy w ciasnej, a zarazem bardzo przecież nieokreślonej formule literatury anarchistycznej, z drugiej zaś zależy mi na tym, by niejako oświetlić z tego punktu widzenia publikacje niemieszczące się we wspominanym ruchu i zobaczyć, co wyniknie z tego eksperymentu. Ze Sztuki radości wydobędę zatem wątki warte zestawienia z polskimi narracjami, a jednocześnie pozwalające umieścić wszystkie przywołane dalej teksty w szerszym kontekście społecznym i kulturalnym. Rodzimymi utworami, do których się odwołam, będą: Na krótko, W powietrzu, Kroniki oporu i miłości oraz zbiór opowiadań Smaki i dotyki Ingi Iwasiów, a także Podróż w stronę czerwieni Sylwii Zientek. Choć listę tę można by poszerzyć, to wydaje się, że na potrzeby mojego artykułu tworzy ona wystarczający materiał porównawczy. Nie sięgam natomiast do prozy wydanej w momencie powstawania oryginału Sztuki radości, ponieważ w polskim życiu literackim dzieło to zaistniało dopiero współcześnie i na tym, najbliższym nam, tle zamierzam je usytuować ${ }^{15}$.

Polski wydawca opisuje Sztukę radości jako „szokującą historię kobiecego wyzwolenia” [Sapienza 2018: okładka]. Choć utwór

Dziękuję Recenzentowi za potwierdzenie znaczenia tej powieści z perspektywy anarchizmu. Obok Komornickiej/Własta sprzed transformacji twórczość Izabeli Morskiej wydaje się dość wyraźnie współgrać z zagadnieniami z obszaru anarchizmu.

15 Zgadzam się z Recenzentem, że ważnym zagadnieniem jest również relacja polskiego feminizmu do anarchizmu. To jednak osobny temat, wykraczający poza ramy nie tylko tego artykułu, lecz także literaturoznawstwa jako dyscypliny. Mam nadzieję, iż w przyszłości uda mi się do niego powrócić. 
rzeczywiście opowiada o uwolnieniu się głównej bohaterki z rozmaitych ograniczeń, to sprowadzanie jego problematyki do emancypacji jednej kobiety lub kobiet w ogólności byłoby uproszczeniem. W tekście mowa bowiem o uzyskiwaniu niezależności ${ }^{16}$ przez człowieka jako takiego, na różnych płaszczyznach ${ }^{17}$, a jedną z nich, której chciałabym się uważniej przyjrzeć, jest seksualnośćc ${ }^{18}$. Inte-

Zdaniem Scarpy [2018: 603] „Sztuka radości jest bardziej niezwykła jako książka o wolności niż o wyzwoleniu”. Rzeczywiście, jeden z głównych tematów powieści to właśnie doświadczanie niezależności, jednak wydaje się, że równie istotne jest jej uzyskiwanie. Na tym aspekcie chciałabym się skupić, ponieważ przynajmniej po części odpowiada on za transformacyjny potencjał tekstu, a poza tym podobne zmagania obrazują interesujące mnie polskie utwory. Więcej na temat wolności w pisarstwie Sapienzy pisała Bazzoni [2018].

Sztuka radości to bowiem „powieść wprowadzająca w wolność ducha i ciała” („Le roman d'initiation à la liberté de l'esprit et du corps” [Navarre, Navarre 2019]), tekst „o buncie przeciwko wszystkiemu, co zniewala” [Kornacka 2018: 147]. Sfer podlegających reinterpretacji z perspektywy poszukiwania niezależności jest $\mathrm{w}$ utworze wiele - kilka $\mathrm{z}$ nich omawiam wyżej. W tym miejscu warto zaś wspomnieć, że dla Modesty pole emancypacji stanowi również język, co dobrze obrazuje poniższy fragment powieści: „Zło kryje się w słowach, które tradycja przedstawia jako absolutne, w wynaturzonym znaczeniu, jakie one wciąż przybierają. Kłamało słowo miłość, dokładnie tak samo jak słowo śmierć. Kłamało wiele słów, kłamały niemal wszystkie. Oto co winnam uczynić: studiować słowa tak wnikliwie, jak się studiuje rośliny i zwierzęta. A następnie oczyścić je z pleśni, uwolnić od naleciałości wiekowej tradycji, wymyślić nowe, a przede wszystkim odrzucić i nigdy więcej nie używać tych, których codzienność używa w nadmiarze, najbardziej zepsutych, jak: wzniosłość, obowiązek, tradycja, wyrzeczenie, pokora, dusza, obyczajność, serce, heroizm, uczucie, litość, ofiara, rezygnacja.

Nauczyłam się czytać książki w inny sposób w inny sposób. Kiedy napotykałam jakieś słowo, jakiś przymiotnik, wyciągałam go z kontekstu i analizowałam, czy można go było użyć w «moim» kontekście. W tej pierwszej próbie zidentyfikowania kłamstwa ukrytego w słowach, sugestywnych nawet dla mnie samej, uświadomiłam sobie, ilu z nich, a co za tym idzie, ilu fałszywych pojęć padłam ofiarą. I moja nienawiść rosła dzień za dniem: nienawiść odkrycia, że zostałam oszukana" [Sapienza 2018: 160].

Ten napisany z perspektywy Modesty cytat problematyzuje to, co za Michelem Foucaultem można by nazwać władzą dyskursu. Władza ta przejawia się w manipulowaniu słowami, które stają się narzędziem opresji i dyscyplinowania. Proponowana przez bohaterkę praca nad językiem nie polega na jego całkowitym odrzuceniu, lecz na przekształceniu pozwalającym wyzwolić środki lingwistyczne i dostosować je do indywidulnych potrzeb. Por. też uwagi Kornackiej [2018: 145-146] i Murek [2018].

Por. także obserwacje Kornackiej [2018: 147-151] na ten temat. 
resuje mnie zatem przede wszystkim - po pierwsze: w jaki sposób autorka przedstawiła ten temat i, po drugie: jaki kontekst dla tego rodzaju rozważań stwarza polska kultura.

Na wstępie wypada zauważyć, że wyzwolenie ciała i seksualności to również zagadnienie podejmowane w refleksji anarchistycznej i anarchofeministycznej. W tym kontekście warto wspomnieć choćby o esejach Emmy Goldman, mówiących o wyzwalającej sile miłości oraz wspólnocie kobiet i mężczyzn, podważanej przez uproszczone rozumienie emancypacji tych pierwszych [Laskowski 2006: 459-460, 470-472; Goldman 2015: 179-187, 196-198]. W powieści Modesta upomina się o to porozumienie, zarazem wiele uwagi poświęcając kwestii kobiecej. Zaniedbań w dziedzinie życia erotycznego upatruje jednak po stronie obu płci.

Najpierw główna bohaterka sama uczy się miłości od swojego kochanka, Carminego, potem zaś stara się zburzyć stereotypowe przekonania, którymi posługuje się jej kolejny partner, Carlo. Carmine, rozpoczynając edukację Modesty, podkreśla niewłaściwe wychowanie kobiet („Niczego was te matki nie uczą, a potem mężczyzna wszystko musi sam [...]" [Sapienza 2018: 132]), co zaskakująco (zważywszy na przywiązanie mężczyzny do tradycyjnych hierarchii społecznych) współbrzmi ze spostrzeżeniami działaczek anarchistycznych [Goldman 2015: 158-159, 192]. Następnie Modesta w relacji z Carlem eksponuje podwójne standardy w wychowaniu kobiet i mężczyzn (o czym wspomnę też dalej). Warto przywołać kilka cytatów wyraźnie ukazujących ten problem:

„Niczego was matki nie uczą”. To prawda, Carmine, nie uczą niczego ani nas, ani was. Ale ja, tak, jak ty miałeś do mnie cierpliwość, będę cierpliwa wobec Carla. [Sapienza 2018: 194]

- [... A może podoba ci się myśl, że się poświęciłam? Nie odpowiadasz? Teraz rozumiem: zrobiłeś sobie ze mnie prywatną świętą do kochania, trochę taką, jak u Dantego. A może wolisz Petrarkę, jak przypuszczam? A więc uczyniłeś sobie ze mnie twoją czystą i świętą Laurę. Biedni chłopcy! Dla nas Pani Bovary, a dla was Laura. Daj spokój, Carlo, jest tysiąc dziewięćset dwudziesty pierwszy! 
- Ciekawe, ilu miałaś tych nauczycieli, co? Teraz rozumiem, dlaczego z taką łatwością się rozbierasz i pieścisz mnie jak...

- No nazwij to, jeśli nie właściwym słowem „dziwka”, to eufemizmem Turatiego. No powiedz, już! Jak pracownica miłości? [Sapienza 2018: 196]

- Wymówki, wszystko to wymówki! Ty wciąż jesteś zakochana w tym mężczyźnie!

- Nie w tym mężczyźnie, Carlo, ale w fizycznej harmonii, która panowała między nami, kiedy uprawialiśmy miłość.

- Robisz się wulgarna, Modesto.

- Dla ciebie wszystko, co prawdziwe, jest wulgarne. [Sapienza 2018: 198; por. też Sapienza 2018: 193-195]

W powyższych fragmentach Modesta piętnuje wychowanie seksualne - odmienne dla kobiet i mężczyzn (w pierwszym wypadku trzeba by zresztą mówić raczej o jego braku), ale szkodliwe dla obu płci. Co więcej, zwraca uwagę na zakorzenienie tych standardów w pewnych stereotypach, a nawet mitach na temat męskości i kobiecości ${ }^{19}$. Mężczyzna funkcjonuje jako sfera aktywna, mająca wyłączne prawo do przeżywania seksualności. Jest to jednak seksualność niejako rozdwojona, co odpowiada dwóm kategoriom kobiet przywołanym przez Modestę i Carla. Jedna z nich to „dziwka” - reprezentująca rozpustę, ale też utożsamiająca kobiecość z cielesnością - druga zaś to „Madonna”, czyli model świętej, bezcielesnej, pozbawionej życia erotycznego wybranki serca ${ }^{20}$. Bohaterka

Za Kornacką [2018: 147-149] warto zwrócić uwagę na jeszcze jedną kwestię związaną z problematyką seksualności, a mianowicie na uwalnianie mowy dotyczącej tej sfery. Modesta, co widać zwłaszcza w przytoczonych wyżej cytatach ze stron 196 i 198, „Z całkowitą swobodą osadza się w języku i w sposób nieograniczony konwencjami, wstydem czy tabu wyraża, opowiada swoje erotyczne pragnienie, namiętność i doświadczaną przyjemność” [Kornacka 2018: 147]. Por. spostrzeżenia badaczki komentujące, także cytowane wyżej, rozmowy głównej bohaterki i Carla na temat seksu oraz punktujące stereotypy kwestionowane przez nią [Kornacka 2018: 150-151].

20 Kornacka [2018: 150; cyt. za: Beauvoir 2003: 415] ujmuję tę kwestię szerzej i za Simone de Beauvoir mówi w tym kontekście o przekonaniu, zgodnie z którym kobieta jest „aniołem, demonem albo sfinksem”. 
kwestionuje przyjętą bezrefleksyjnie przez kochanka rozdzielność obu wzorców i związane z nimi wartościowanie. Upomina się także o prawo kobiet do wiedzy na temat sztuki miłości fizycznej, zaznaczając zarazem, że nie jest ona czymś wrodzonym, lecz pewną techniką, której dla satysfakcji wszystkich osób w niej uczestniczących trzeba się nauczyć. Wreszcie, co szczególnie szokujące dla Carla, a oczywiste dla przecież znacznie mniej postępowego Carminego, podkreśla, iż przyjemność cielesna należy się zarówno mężczyznom, jak i płci przeciwnej.

Inny istotny wątek dotyczący seksualności to kwestia homoerotycznych doświadczeń ukazanych w powieści ${ }^{21}$. O ile cielesna zażyłość Modesty i Beatrice jest, jak się wydaje, traktowana nieco instrumentalnie, jako inicjacja seksualna i wstęp do heteroseksualnych praktyk [por. Sapienza 2018: 134], o tyle dużo późniejsze związki głównej bohaterki z Joyce [por. np. Sapienza 2018: 358-368] i Niną [Sapienza 2018: 496-52] przedstawiają się jako samoistna wartość. Dodatkowo księżna stara się walczyć z uprzedzeniami pierwszej ze wspomnianych kobiet, która - pod wpływem uproszczonej interpretacji Freudowskiej psychoanalizy - wstydzi się swoich upodobań i uważa je za przejaw nienormalności [Sapienza 2018: 405-408, 411-412]. Co ważne, Modesta nie traktuje seksualności esencjalistycznie. Podkreśla, że ukierunkowanie pożądania może się zmieniać w życiu człowieka [Sapienza 2018: 411-412] - nie ma zatem potrzeby przypisywać jednostkom tożsamościowych etykietek ${ }^{22}$.

Na gruncie polskiej literatury warto się przyjrzeć, w jaki sposób autorki, mówiąc nieco górnolotnie, obalają mity na temat kobiecych seksualności i życia erotycznego. Interesuje mnie zarówno się już w niektórych wczesnych teoriach anarchistycznych, m.in. Goldman i Emile’a Armanda, choć nie bez oporu wielu działaczy [Laskowski 2006: 475-479]. Jak zauważa Kornacka [2018: 150]: „Goliarda Sapienza ante litteram rozwiązuje przymusowy węzel, który splata ciało (rodzaj biologiczny), gender (rodzaj kulturowy) i pragnienie, o którym napisze Judith Butler" [por. też Butler 2008: 151]. Modesta zwraca również uwagę na różnice w wychowaniu dziewcząt i chłopców (zob. także dalej), eksponując społeczny i kulturowy wymiar płci: „Uczyli tego, by zamknąć was, chłopców, w pancerzu obowiązków i fałszywych przekonań. Tak samo jak nas, kobiety: inne obowiązki, pancerze z jedwabiu, ale skutek ten sam" [Sapienza 2018: 400]. 
pozytywny aspekt tych problemów, jak i ich druga, skupiona na odrzuceniu pewnych praktyk, strona.

Zacznę od utworów Iwasiów. W niektórych opowiadaniach ze zbioru Smaki i dotyki [Iwasiów 2006: 32-33, 43-66, 169-173], a także w powieściach $W$ powietrzu [Iwasiów 2014: 7-10, 70-71] oraz Kroniki oporu i miłości [Iwasiów 2019: 24-25, 29, 33-34, 90-91, 110, 246, 273, $288]^{23}$ poznajemy bohaterki afirmujące swoją cielesność i życie erotyczne, rozwijane zarówno w heteroseksualnych, jak i damskodamskich relacjach. Często jest to jednak trudna akceptacja, ponieważ opiera się na smutku, bólu, zagrożeniu utratą, niespełnieniu [Iwasiów 2006: 41, 60-66, 140-155, 273-177; 2014: 46-47, 194-196, 200-203, 2019: 201-202] lub, co jest widoczne zwłaszcza w utworze W powietrzu, wynika z poczucia samotności i maskuje nieprzepracowane doświadczenia z dzieciństwa czy wręcz bazuje na pewnych szerszych kulturowych traumach [Iwasiów 2014: 66-67, 85-86] $]^{24}$. Co więcej, tematem ostatniej z wymienionych powieści okazuje się nie tylko kobieca seksualność, lecz także seksualność sama w sobie, uwolniona od płci biologicznej i społeczno-kulturowej - w taki właśnie, nieograniczony żadnymi tożsamościowymi etykietkami, sposób narratorka-bohaterka postrzega swoje pożądanie, zbliżając się tym samym do perspektywy queerowej ${ }^{25}$. Zarazem jednak - choć niekiedy teksty te ukazują historie budzącego się życia erotycznego [Iwasiów 2006: 178-179; Iwasiów 2014: 7-10, 46-53; Iwasiów 2019:

Por. też fragmenty pełnego swobody i erotycznej radości pamiętnika pisanego przez Helenę - babcię partnera Małgorzaty [Iwasiów 2019: 61-66].

Niekiedy zresztą owej akceptacji brakuje - Iwasiów przedstawia bowiem także negatywne doświadczenia związane z cielesnością i seksualnością lub dystans wobec nich, co można szczególnie dobrze zaobserwować w zbiorze Smaki i dotyki [Iwasiów 2006: 5-18, 21, 23, 26, 132, 234].

25 Być może zresztą „pożądanie” to zbyt wąskie określenie na siłę pobudzającą bohaterkę do działania. Ona sama określa ją mianem „tamagotchi” [por. np. Iwasiów 2014: 7-10] i przedstawia w ten sposób: „Mieliśmy lepsze i gorsze okresy. [... Pewne, pewny, nie wiem, jakiej było płci wówczas, gdy się go zaledwie domyślałam [...]. Nie czułam w nim kobiety, miało w sobie niedookreśloność, jak płód niezbadany ultrasonografem" [Iwasiów 2014: 9]. Tamagotchi, kumulujące w sobie pożądanie, popęd i seksualność, okazuje się czymś, co należy oswoić i zaakceptować [Iwasiów 2014: 10]. Brzmi to jak queerowy postulat, ale może okazać się także punktem łączącym powieść Iwasiów z pozytywną wizją miłości fizycznej przedstawioną i w książce Sapienzy, i w teoriach anarchistycznych. 
24-25, 35] - to cielesność i seksualność są w nich czymś danym: otwartym na przekształcenia i dynamicznym, ale mimo wszystko w jakiś sposób intuicyjnym. To odróżnia przywołane książki Iwasiów od Sztuki radości. W powieści Sapienzy pragnienie również jest spontaniczne, przedkulturowe, ale, jak już wspomniałam, wyrażanie i współodczuwanie go z inną osobą jawi się jako proces wymagający pracy i nauki, na co, jak się wydaje, mniejszy nacisk położono we wspomnianych utworach Iwasiów ${ }^{26}$. Można powiedzieć, że o ile w omówionych wyżej polskich tekstach życie erotyczne istnieje „tak po prostu”, a zarazem często sprawia ból, o tyle w Sztuce radości zakłada się, że jeśli stanowi ono efekt edukacji, samoświadomości i współpracy, to ma szansę przynosić głównie przyjemność.

Ów ból, pewna smutna refleksyjność szczególnie wyraźnie dochodzą do głosu w innej powieści Iwasiów - Na krótko. Atmosfera ta po części wynika z narracji o schyłku dwóch małżeństw: Sylwii i Tomka oraz Ruty i Kazika [Iwasiów 2012: 11-15, 44-46, 48-50, 52-54, 73-74, 119-120, 128-129, 135-137, 147-152, 158-160, 189-190, 193-198, 254, 263-264, 269-272, 275, 278-279, 288-290, 304-305, 311, 316-317, 354-364 $]^{27}$, a także występowania tajemniczej choroby, polegającej na problemach z pamięcią i koncentracją, u pierwszej z wymienionych bohaterek [Iwasiów 2012: 57-64, 100-114, 178-181, 204-205, 293-294, 310-312 $]^{28}$. To jednak nie wszystko. Istotne są też opisy pierwszych - niełatwych, bo w oczywisty sposób budowanych bez doświadczenia, wiedzy i umiejętności - przeżyć seksualnych młodej dziewczyny [Iwasiów 2012: 254-261], oraz realistyczne, pozbawione entuzjazmu przedstawienia doznań dojrzałych kobiet [Iwasiów 2012: 50, 254]. W tym utworze Iwasiów ukazuje bowiem również, można powiedzieć, seks codzienny ${ }^{29}$. Nie traumatyczny,

Nie oznacza to, że tych wątków nie ma wcale. Jak już wspomniałam, przywołane utwory przedstawiają również inicjację bohaterek w życie seksualne, z czym wiążą się przecież opisy poznawania i uczenia się życia erotycznego.

27 Również w Kronikach... mowa o rozpadzie małżeństwa głównej bohaterki (zob. dalej) i schyłku jej związku z partnerką Anną [Iwasiów 2019: 355-359, 367-368].

Pada też sugestia, że jest to schorzenie „z autoagresji” [Iwasiów 2012: 111], co dodatkowo wskazuje na mentalną kruchość postaci.

Choć nie wyłącznie, ponieważ w książce znajdziemy też opisy znacznie bardziej satysfakcjonujących doznań [Iwasiów 2012: 354-361]. Warto także zwrócić uwagę 
ale zwyczajny - taki, jakiego udało się uniknąć Modeście, ale jaki może być udziałem wielu czytelniczek.

O codzienności życia erotycznego, choć nieco mniej przyjemnej, opowiada także Ewa, narratorka-bohaterka Podróży w stronę czerwieni Zientek. W tle utworu rysuje się historia seksualnego odkrywania siebie jako kobiety: od nazwania tego, co jej nie odpowiada w intymności z mężem [Zientek 2016: 47-49, 86, 89, 99, 106-107, 113, 134, 136, 169, 182, 304-306, 313], i odkrycia w sobie homoerotycznych fascynacji kobietami [Zientek 2016: 47-48, 308 $]^{30}$, do zrealizowania ukrytych pragnień [Zientek 2016: 312-313] ${ }^{31}$. Wydaje się, że stłumienie i blokada, z którymi początkowo boryka się postać, wynikają z szerszego kontekstu kulturowego. Ewa, choć otwarta na świat, została wychowana w tradycyjnym modelu ról seksualnych, podtrzymywanym zresztą także przez kobiety. Wyraźnie wskazuje na to zacytowana przez narratorkę rozmowa:

Wtedy [na początku związku z Pawłem - późniejszym mężem bohaterki - K.L.] nigdy nie miałam orgazmu, bo Paweł nie umiał mnie odpowiednio dotykać. W czasie studiów seks miał raczej przygodny charakter, a pełną satysfakcję osiągałam tylko wtedy, gdy partner umiejętnie pobudzał moją łechtaczkę. Paweł tego nie robił, a ja wstydziłam się mówić o swoich potrze-

na wzmianki o początku pożycia Ruty i Kazika - euforycznym i dającym radość obu stronom, choć zarazem opartym na pewnej konserwatywnej równowadze. Mężczyzna nie pozwalał bowiem kobiecie przejmować inicjatywy i eksperymentować [Iwasiów 2012: 49], potwierdzając zarazem swoje przywiązanie do tradycyjnego podziału ról (podobną postawę przyjmował także brat Ruty - Witek [Iwasiów 2012: 221-225]). Być może m.in. z tego powodu „z czasem to udane pożycie zaczęło $[\ldots]$ nudzić” [Iwasiów 2012: 50] bohaterkę.

Jednak w pewnym momencie Ewa, dzięki rozmowie z przyjaciółką, zaczyna interpretować swoje zainteresowanie kobietami jako wyraz seksualnych pragnień, a także potrzeby czułości, których jej mąż nie potrafił (choć byłby w stanie) zaspokoić [Zientek 2016: 181-183].

W dosłownym sensie to ostatnie dokonuje się dzięki mężczyźnie - Simonowi, kochankowi Ewy. Nie można jednak zapominać, że przemiana postaci odbywa się przecież w dużej mierze pod wpływem Komornickiej/Własta, która/który inspiruje Ewę do rozpoczęcia dosłownej i metaforycznej podróży. Choć zatem główna bohaterka powraca na bezpieczne tory heteroseksualności, to w powieści nie niknie zainteresowanie nienormatywnymi tożsamościami (zob. też dalej). 
bach. Bardziej doświadczona znajoma, której się zwierzyłam, powiedziała, że na tak wczesnym etapie związku jest jeszcze za wcześniej na orgazm, trzeba się najpierw dopasować, a zresztą orgazm jest przereklamowany i nie ma aż takiego znaczenia. [Zientek 2016: 49]

Dopiero później Ewa trafia na przyjaciółkę, która pomaga jej spojrzeć na seks z innej strony [Zientek 2016: 182-183, 308].

W przytoczonym w poprzednim akapicie cytacie zwraca również uwagę tabu całkowicie zinterioryzowane przez Ewę, wstydzącą się mówić, czego potrzebuje. Ten lęk przed własnymi ciałem i seksualnością powraca także w dalszej części książki, gdy bohaterka poznaje swojego przyszłego kochanka i uświadamia sobie, że seks z mężem, choć niesatysfakcjonujący, był bezpieczny, bo nie wymagał odkrywania siebie się na nowo („[... ] z przerażeniem myślałam o tym, że miałabym się rozebrać przed kimś obcym, kto nie jest Pawłem" [Zientek 2016: 309]). Dodatkowo kobieta słusznie zwraca uwagę, iż niechęć do fizycznej miłości może wynikać z zakodowanych w niej relacji władzy:

Pomyślałam, że z poczuciem podległości, jakie wynika z seksu, wiąże się jego deprecjacja, dlatego nigdy nie pozwalałam sobie bez reszty oddawać się przyjemności, całkowicie się w niej zatracić. Przypomniałam sobie, jak Paweł pytał mnie po stosunku, czy oddałam mu się z miłości czy pożądania. Złościło mnie to, bo uważałam, że to nie powinien być akt oddania się, lecz przyjęcia, przyzwolenia, dopuszczenia do siebie i kobiecych tajemnic. [Zientek 2016: 169]

Upominając się o wzajemny szacunek i miłość, Ewa, podobnie jak Sapienza i Goldman, akcentuje piękno seksu opartego na wzajemnym porozumieniu.

Inną wartą przywołania kwestią jest przedstawiony w Sztuce radości wizerunek rodziny. Jej tradycyjny wariant stanowi z perspektywy Modesty albo ograniczenie, od którego trzeba się oderwać (wskazuje na to bezkompromisowy, brutalny sposób, w jaki bohaterka wyzwoliła się od matki i siostry, a później od dwóch 
dobrodziejek: zakonnicy Leonory i księżnej Gai [Sapienza 2018: 27-28, 61-62, 136-144]), albo coś, czego znaczenie należy drastycznie zminimalizować (tak postać postąpiła ze swoim oficjalnym małżeństwem [Sapienza 2018: 103-104, 112-121, 145]) 32. Z kolei nowy model życia rodzinnego, wprowadzony przez główną bohaterkę, dający się zresztą wpisać w szerszy kontekst anarchistycznej i anarchofeministycznej krytyki instytucji małżeństwa i tradycyjnego modelu rodziny [Antonów 2004: 287-288; Laskowski 2006: 447-453, 456-466, 470-472, 474-475; Goldman 2015: 189-198] ]33, jest formulą znacznie bardziej otwartą, nie tylko w kontekście erotycznym, choć kwestia swobody doboru partnerów i partnerek seksualnych oraz pochwały miłości uwolnionej od zobowiązań i przymusów także ma duże znaczenie. Jednakże chodzi o coś więcej, ponieważ omawiana wizja stanowi szerszą propozycję przeformułowania ogółu relacji międzyludzkich, które miałyby być oparte na niezależności i wzajemnym poszanowaniu odrębności [por. też Serkowska 2019: 79; Kornacka 2018: 152]. Wszelkie próby nadużywania władzy, naruszania cudzej swobody bohaterka ze stanowczością odrzuca ${ }^{34}$ - nawet jeśli wychodzą ze strony jej własnego dziecka - dystansując się od

Ten wątek podkreśla zresztą, że Modesta znajduje się niejako na granicy dwóch światów. Decydując się na całkowicie pragmatyczne i fasadowe małżeństwo (krok ten jest zresztą fabularnie uzasadniony), bohaterka wpisuje się w normy, które sama podważa, co jednocześnie daje jej większą swobodę naruszania tychże reguł. Za Hanną Serkowską [2019: 79] można więc powiedzieć, że jej „postawy są płynne, oscylują między schematami patriarchalnymi a ich zwalczaniem, uwalnianiem się od nich”.

33 Trzeba przy tym pamiętać, że krytyka ta odbywała się w określonym kontekście, a jej punktem odniesienia była instytucja małżeństwa znacznie przecież zmodyfikowana przez przemiany, jakie zaszły w obyczajowości zachodniej w 2. połowie xx wieku. Pewne aspekty wspomnianych dyskusji, obecne - o czym piszę dalejrównież w Sztuce radości, pozostają jednak nadal aktualne.

Założenie to działa jednak w obie strony, ponieważ Modesta przyznaje, że jako matka i opiekunka powinna pozostawić dzieciom pełną swobodę, także pod względem uczuć do samej siebie: „Uważać się za kogoś nieodzownego dla innych istot, na dodatek bezbronnych, tylko dlatego że je karmisz, to najbardziej okrutna forma paternalizmu. [...] Ja bym zorganizowała syndykat dzieci przeciwko temu straszliwemu duetowi, jakim są ojciec i matka, którzy za kawałek chleba i zabawkę żądają ceny miłości, zbyt wysokiej dla jakiejkolwiek normalnej jednostki” [Sapienza 2018: 379]. 
osób stosujących podobne praktyki3 ${ }^{35}$. Dla zobrazowania powyższych uwag warto przytoczyć fragmenty wypowiedzi Modesty z jej rozmowy z synem Prandem:

[... ] w tym domu nie szpieguje się nikogo i nie narusza niczyjej prywatności. [...] A więc zabraniam ci przekraczania przestrzeni wolności, która przynależy do mnie, tak samo jak tej, która przynależy do 'Ntoniego, Laleczki, Meli i Jacopa ${ }^{36}$. [...] nie mam najmniejszego zamiaru ulegać szantażom młodzieży! [...] w imię twojej młodości i tego, że jestem twoją matką, mówisz, że powinnam poświęcić się tobie i wyłącznie tobie! Właśnie teraz żądasz ode mnie [...], bym wybierała między Joyce a tobą, a ja odrzucam twój szantaż i odpowiadam, że nie jestem ani twoją, ani jej własnością, tak samo jak ty nie jesteś absolutną własnością Modesty. Jeśli możemy się kochać nawzajem bez zaborczości, kochajmy się, ale jeśli to napięcie godne właścicieli ziemskich będzie się dalej zaostrzać, doradzam ci, byś na jakiś czas wyjechał i przemyślał to wszystko. [...] Dlugie mieszkanie ze sobą zawsze powoduje napięcia i nie istnieją ani więzy krwi, ani inne głupoty, które mogą temu zaradzić. [Sapienza 2018: 433-434] $]^{37}$

Podobne pragnienie swobody przejawia się w intymnych związkach Modesty, która np. opanowując swoje uczucie do Matti, a zarazem odpowiadając na pragnienie dominacji okazywane przez kochanka [Sapienza 2018: 263-264], odkrywa, że tym, czego potrzebuje, jest „[s]łodycz braku oczekiwania, niezależności od cudzej woli” [Sapienza 2018: 265].

Jak bowiem słusznie zauważa Kornacka [2018: 151] (por. też cały fragment artykułu dotyczący macierzyństwa [Kornacka 2018: 151-153]), bohaterka kocha Pranda i wszystkie będące pod jej opieką dzieci „miłością wielką, ale niespójną z tym, co zawiera się w archetypie matki”. Wizja ta, podważająca tradycyjny model rodziny, może być szokująca zarówno dla polskich, jak i włoskich czytelników i czytelniczek [zob. także Kornacka 2018: 151-152]. Są to imiona innych domowników - członków i członkiń specyficznie rozumianej rodziny Modesty.

Por. też komentarz Kornackiej [2018: 153] dotyczący tego fragmentu. 
W szerszej perspektywie bohaterka przeciwstawia się jednak nie tylko konkretnym przymusom, mającym wynikać z relacji interpersonalnych, w które jesteśmy uwikłani, lecz także ograniczającemu, jej zdaniem, naciskowi na trwałość związków międzyludzkich. To oczywiście przekłada się również na określony sposób widzenia więzi rodzinnych [por. też Serkowska 2019: 79]. W rozmowie z Joyce Mody zauważa:

[...] dla mnie jest oczywiste, że wszystkie relacje są bez przyszłości, ponieważ ludzie się zmieniają, a przy tej zmianie starzeją się w nas relacje i człowiek potrzebuje nowych... A jakby się dobrze zastanowić, to może właśnie dlatego ludzie starzeją się przedwcześnie, że zmuszają się do nielicznych uświęconych relacji i mają przed oczami wciąż te same widoki. [Sapienza 2018: 411 (por. też np. s. 450); zob. także Serkowska 2019: 79]

Modesta nie zapomina o fascynacji erotycznej. Jej zdaniem również w tej sferze powinna panować wolność nieograniczona mitem trwałości. Z tego założenia wynika konkretna interpretacja instytucji małżeństwa mającego być

absurdalnym kontraktem, który upokarza zarówno mężczyznę, jak i kobietę. [...] gdy się spotyka mężczyznę i on się podoba, kocha się go aż do... no, dopóki to trwa. A potem ludzie się rozstają, o ile to możliwe, jak dobrzy przyjaciele. [Sapienza 2018: 464$]^{3^{8}}$

Z szerszej perspektywy uwagi te wpisują się w głoszoną także przez ruchy anarchistyczne pochwałę wolnej miłości. Wydaje się bowiem, że np. pod poniższym spostrzeżeniem Modesty mogłaby się podpisać Goldman: „[...] miłość nie jest ani absolutna, ani wieczna, ani też nie istnieje włącznie między mężczyzną a kobietą i najlepiej w uświęconej sakramentem postaci” [Sapienza 2018: 159]. Podobnie na tę kwestię zapatruje się Nina - kochanka i przyjaciółka, a także, jak sama mówi, „towarzyszka” [Sapienza 2018: 508] Modesty. Kobieta z niezadowoleniem zauważa: „W Rosji odrzucili wszystko to, co miało znaczenie dla wolności jednostki. Minęło ledwie kilka lat, a już zapomnieli o wolnej miłości i powrócili do małżeństwa” [Sapienza 2018: 508]. 
Zakończenie powyższego cytatu wskazuje przy okazji, że tolerancja dla nietrwałości więzi ludzkich nie oznacza dla Mody instrumentalnego traktowania relacji międzyludzkich. Chodzi bowiem nie tyle o bezwarunkowe odrzucanie przemijającego, ile o pogodną akceptację zmian, z zachowaniem szacunku dla wartości i pozytywnych emocji przyniesionych przez konkretną więź; jest to dobrze widoczne w opisie schyłku związku bohaterki z Joyce [Sapienza 2018: 412, 417-418, 445] $]^{39}$.

Na marginesie trzeba dodać, że niechęć księżnej do zaborczości wiąże się z lękiem przed fanatyzmem, którego najżywszym wcieleniem jest dla postaci z powieści faszyzm. Niepokój ten przeziera choćby przez pozornie żartobliwy dialog Modesty i Niny. Druga z nich, reagując na zachowanie Pranda, wyznaje:

Gdybym to ja rządziła, to tych wszystkich Prandów posłałabym od razu, żeby sobie usiedli grzecznie i wygodnie wśród kwiatów i szemrzących strumyków, i przeczytali, co Wolter pisze o fanatyzmie... Co za fanatyk, uch! [Sapienza 2018: 539] $]^{40}$

Bardzo ważnym wątkiem powieści, dotyczącym zarówno życia rodzinnego, jak i seksualności oraz cielesności, jest również aborcja. Modesta dokonuje tego zabiegu podczas drugiej ciąży, a początkowo namawia do niego także Inès - towarzyszkę swojego męża [Sapienza 2018: 212-213] ${ }^{41}$. Choć stosunek powieści do feminizmu jest niejednoznaczny (zob. dalej), to akurat w tym

Warto też wspomnieć o jeszcze jednym aspekcie Modestowej walki o niezależność, a mianowicie o dążeniu do wyrwania się z relacji niszczących psychicznie i emocjonalne - po raz kolejny dobrym przykładem jest związek z Joyce [por. np. Sapienza 2018: 445-450].

40 Dla ścisłości trzeba także dodać, że Modesta nie usprawiedliwia fanatyzmu niezależnie od tego, po której stronie barykady miałby się on znaleźć. Stąd też obawa przed stosowaniem terminu „ateizm”, uznawanego przez bohaterkę za zbyt kategoryczny, jednostronny i oparty na nieuzasadnionej pewności siebie. $\mathrm{Z}$ tego względu księżnej bliższy jest agnostycyzm, uznany za bardziej otwartą i złożoną postawę [Sapienza 2018: 462]. Na marginesie warto również zauważyć, iż w tych uwagach pobrzmiewają poglądy samej autorki, opisującej siebie jako ateistkę wylącznie ze względów strategicznych [Pellegrino 2018b: 635-636]. postanawia usunąć kolejne ciąże [Sapienza 2018: 455]. 
punkcie utwór wyraźnie - nawet jeśli w niezamierzony sposób wpisuje się w debaty prowadzone w obrębie tego nurtu lub wręcz je wyprzedza [por. też Kornacka 2018: 149-150]. Chodzi bowiem nie tylko o odrzucenie przymusu macierzyństwa, lecz także o kolejny krok w wyzwalaniu się spod wpływu mężczyzny, który nie może już szantażować kobiety potencjalną ciążą. Ten drugi problem jest bezpośrednio przywołany w rozmowie Modesty i Carminego:

- [...] nie żartuj z mężczyzny, bo jeśli zechcę, przygwożdżę cię do siebie dzieckiem. A wtedy przynajmniej przez rok będziesz musiała o mnie myśleć.

- Pomyliłeś się w rachubach, Carmine. Myślisz, że byłabym taka beztroska przez te miesiące, gdybym nie miała w zanadrzu sposobu, by zostać wolna? [Sapienza 2018: 245]

Co więcej, bohaterka odrzuca przywołany przez kochanka stereotyp, zgodnie z którym usuwanie ciąży wiąże się z bólem fizycznym i psychicznym ${ }^{42}$ :

- [... to, co masz na myśli, sprowadza cierpienie, a często śmierć.

- Wiedziałam, że to powiesz! Nie dla kogoś, kto ma pieniądze, Carmine, pieniądze i wiedzę. Byłam chora albo brzydka tej nocy, kiedy wróciłeś?

- Piękniejszą i silniejszą cię zastałem, daj się pocałować.

- A ja kilka dni wcześniej, w czyściutkiej salce i bez cierpienia, prostym zabiegiem uwolniłam się od przekleństwa. I zrobię

Jednocześnie pragmatyzm pozwala Modeście posługiwać się podobną, opartą przede wszystkim na religii, argumentacją, gdy ze względu na zmianę okoliczności (por. „Jak powiedział Carlo, skoro nie wiadomo dokładnie, w którym jest miesiącu, dziewczyna mogłaby nam umrzeć przy zabiegu" [Sapienza 2018: 223]) postanawia jednak zachęcić Inès do urodzenia dziecka („,- [...] Ale nie zapominaj, że jeśli usuniesz, popełnisz grzech. [...] Niesamowite są te małe pobożne duże! Rzucały na siebie i zrzucały słowo «grzech» zupełnie jak cyrkowiec żonglujący lekkimi białymi piłeczkami. [... . - [...] Pamiętaj, że aborcja jest czymś potwornym dla duszy i ciała" [Sapienza 2018: 223]). Jest oczywiste, że księżna traktuje ten sposób rozumowania czysto instrumentalnie (nieprzychylny obserwator mógłby wręcz powiedzieć: cynicznie) - sama bowiem tuż po rozmowie z Inès - udaje się na zabieg usunięcia ciąży [Sapienza 2018: 223-224]. 
to jeszcze raz, jeśli przyjdzie ci do głowy przygwoździć mnie dzieckiem do siebie. Modesta nie ma pana nad sobą. [Sapienza 2018: 245-246] $]^{43}$

Dla Modesty aborcja okazuje się zatem znakiem wielorakiego wyzwolenia: nie tylko od narzucanych ról, lecz także od emocji związanych zarówno z macierzyństwem (postać obala m.in. mit zakładający automatyczną i nienaruszalną więź matki z dzieckiem od momentu poczęcia), jak i z samym procesem usuwania ciąży, mającym wywoływać jedynie cierpienie i wyrzuty sumienia ${ }^{44}$.

W swoich powieściach relacje rodzinne interesująco przedstawia także Iwasiów. Dobrym przykładem jest $W$ powietrzu, którego główna bohaterka, idąc niejako za głosem impulsu, decyduje się na samotne macierzyństwo [Iwasiów 2014: 131-153]. Przy okazji w czym nieco upodabnia się do bezkompromisowości Modesty usuwa więc ze swojego życia ojca dziecka [Iwasiów 2014: 146-148, 150-151, 153]. Warto też wspomnieć o Kronikach..., dyskutujących z tradycyjnym modelem rodziny. Małgorzata, narratorka-bohaterka, rozprawia się ze swoją przeszłością - zwłaszcza z trudnym dzieciństwem, przeżytym w cieniu matki borykającej się z problemami psychicznymi - kwestionując mit o serdecznych i nierozerwalnych więziach między rodzicami a dziećmi i dowartościowując relacje poziome, między rodzeństwem [por. np. Iwasiów 2019: 22-23, 68-87]. W późniejszym życiu główna bohaterka musi się mierzyć z rozstaniem z mężem [Iwasiów 2019: 29-35]. To krótko trwające małżeństwo zostało zresztą zawarte szybko: po tym, jak młoda Małgorzata wcześnie zaszła w ciążę [Iwasiów 2019: 110]. Iwasiów, nie opatrując tego faktu żadnym dodatkowym komentarzem, pod-

Jak widzimy, bohaterka zaznacza zarazem, że bezpieczna aborcja jest ekonomicznym przywilejem. Na marginesie trzeba zauważyć, iż we współczesnej Polsce zdanie to nie straciło aktualności.

Kluczowe wydaje się właśnie to, że aborcja jest dla Modesty jednym z wielu narzędzi wyzwolenia i przede wszystkim ze względu na tę funkcje zyskuje w oczach bohaterki uzasadnienie. Odmiennej ocenie podlega, gdy ma być specyficzną formą męczeństwa, a jednocześnie pognębienia innych, jak w przypadku Inès: „Nikczemna Inès! Nieprzyjaciółka kobiet i mężczyzn, tchórzliwa kobieta niezdolna do rodzenia ... Po śmierci Carla miała cztery aborcje, a każda kolejna przychodziła jej z większą łatwością. Sądziła, że poprzez praktykowanie osobistej kalwarii wypłaci się za swoją winę" [Sapienza 2018: 455]. 
waża tabu i społeczne napiętnowanie dotykające młode matki. Po odejściu męża Małgorzata zaczyna nawiązywać relacje zarówno z mężczyznami, jak i, później, z kobietami. W konsekwencji tworzy relacje zdecydowanie wybiegające poza tradycyjny polski model rodziny [Iwasiów 2019: 40, 90-91, 171, 218]. Co ważne, powieść, podobnie jak Sztuka radości, ukazuje też przemijanie i przemiany relacji międzyludzkich, widoczne m.in. we wspomnianym wątku uwalniania się spod wpływu rodziców. W swoim dążeniu do niezależności Małgorzata może nieco przypominać Modestę, choć jest zarazem postacią zdecydowanie słabszą, pełną wątpliwości i nie tak bezkompromisową, jak główna bohaterka Sztuki radości. Wrażliwość i niepewność kobiety da się zaobserwować głównie w historii jej rozstawania się z Anną. Akurat w tym punkcie Kroniki... są nie tyle powieścią o uwalnianiu się od czegoś/kogoś, ile narracją o smutku wynikającym z przemijania więzi - uczucia, którego, jak już wskazywałam, w utworze Sapienzy jest stosunkowo niewiele, ponieważ zastąpiła je akceptacja zmian i docenianie wartości płynących nawet z wygasających relacji.

W Podróży... Zientek również pojawia się pewna reinterpretacja związków rodzinnych. Można przypuszczać, że narratorka-bohaterka czuje się uwięziona w obowiązkach matki i pani domu [Zientek 2016: 85-86, 101] oraz, przede wszystkim, w coraz mniej satysfakcjonującym małżeństwie. Czasowe rozstanie $\mathrm{z}$ mężem [Zientek 2016: 86-87, 134-137, 141], a zwłaszcza tropiący losy Komornickiej/Własta wyjazd [por. Zientek 2016: 152-154] pozwala Ewie z dystansem spojrzeć na swoją dotychczasową sytuację i przyjmowane role społeczne. $\mathrm{Z}$ perspektywy niniejszych rozważań kluczowe jest to, że bohaterka podejmuje refleksję nad własnymi uwikłaniami i bezwiednie realizowanym modelem życia rodzinnego. Oczywiście odrzucenie najbardziej rozpowszechnionego porządku niekoniecznie i nie zawsze musi być uznane za najlepsze wyjście. Istotne jest jednak to, że w swojej powieści Zientek, podobnie jak Iwasiów i Sapienza, proponuje zrewidowanie przekonań o naturalności i niewzruszalności tradycyjnych wyobrażeń rodziny, tworząc zarazem przestrzeń dla alternatywnych rozwiązań ${ }^{45}$. 
Inny niezwykle istotny wątek Sztuki radości to zaangażowanie polityczne, przejawiające się w różny sposób przez całą powieść. Na samym początku śledzimy wspomniane już działania Modesty, mające zapewnić bohaterce niezależność. Z szerszej perspektywy chodzi więc o walkę o wolność jednostki. Sceny z pobytu małej Mody w klasztorze można również interpretować jako krytykę skostniałych, opartych na obłudzie (kościelnych) instytucji. Dorastając, Modesta, m.in. dzięki lekturom z biblioteczki stryja Jacopa (nazywanego zresztą przez księżnę Gaję heretykiem), pielęgnuje i rozwija swoją buntowniczą, sprzeciwiającą się dogmatom i staremu porządkowi świata naturę [Sapienza 2018: 79-80, 111-113]. Kolejne, zmierzające do emancypacji na indywidualnej płaszczyźnie decyzje dojrzałej bohaterki, takie jak: sprzedaż majątku [Sapienza 2018: 157-158], usunięcie ciąży, swobodne relacje erotyczne z mężczyznami i kobietami (zob. wyżej), można też usytuować w szerszym kontekście społecznego wyzwolenia.

Oczywiście nie bez znaczenia pozostaje czas historyczny przedstawiony w utworze. $Z$ jednej strony ukazano w nim rozwój włoskich (i nie tylko) ruchów socjalistycznych, komunistycznych i anarchistycznych, z drugiej zaś wzrost siły faszystów we Włoszech i ich dojście do władzy. Pierwszy wątek obserwujemy właściwie nieustannie od momentu, w którym w świecie przedstawionym pojawia się doktor Carlo Civardi, wtajemniczający Modestę w działalność lewicowych organizacji. Bohaterka, początkowo bardzo zaangażowana w ich aktywność, szybko się nią rozczarowuje, dostrzegłszy jej zachowawczość (w tym tradycyjne podejście do ról genderowych [Sapienza 2018: 282-283]),

nie nieobecną u nas instytucjonalną edukację seksualną i tabu, jakim pozostaje życie erotyczne, zwłaszcza kobiet. Omawiane utwory Sapienzy, Iwasiów i Zientek podejmują te marginalizowane problemy i reinterpretują modele - przestarzałe już z perspektywy Modesty, a mimo to nadal bardzo rozpowszechnione w naszym kraju. Na marginesie trzeba wspomnieć, że na szczęście w przypadku tej zaniedbanej dziedziny kształcenia podejmowanych jest wiele oddolnych, pozaliterackich inicjatyw, m.in. takich jak magazyn „G'lrs Room”, Instytut Pozytywnej Seksualności, a także głośna kampania \#sexedpl [Sexed.pl 2020] i publikacja Anji Rubik [2018] Sexedpl czy książka Voki Ilnickiej [2020] Uniesienie spódnicy. Seksualne doświadczenia i kobieca moc. Oczywiście nie można też zapominać o wydanej już w 1978 roku Sztuce kochania Michaliny Wisłockiej. 
powtarzanie schematów i tendencję do idealizowania własnych przekonań ${ }^{46}$ [Sapienza 2018: 186-188, 190-191]. Nie oznacza to jednak, że całkiem odrzuca lewicowe postulaty - do tego problemu jeszcze powrócę.

O stosunku bohaterek i bohaterów do faszyzmu już wspomniałam. W tym miejscu trzeba zaś zaznaczyć, że przed wojną i w jej trakcie dom Modesty funkcjonuje jako miejsce oporu, wymykające się represjom tak długo, jak to możliwe. Ostatecznie księżna trafia jednak do więzienia, gdzie poznaje Ninę - postać otwarcie wprowadzającą do powieści hasła anarchistyczne [por. np. Sapienza 2018: 558]. Co ważne, jest to anarchizm zdecydowanie bardziej praktyczny niż teoretyczny - kobieta pochodzi bowiem z ubogiej, od dawna politycznie zaangażowanej rodziny, wcielającej rewolucyjne postulaty w codzienność [Sapienza 2018: 494-495, 497, 518]. Nina, podobnie jak Modesta, praktykuje też założenia wolnej miłości [Sapienza 2018: 508, 519]. Dodatkowo zaraża Mody swoimi energią i optymizmem, by wyrywać główną bohaterkę z marazmu i nauczyć ją na nowo „sztuki radości” [Sapienza 2018: 500-502, 517-520, 539, 545].

Jednak koniec wojny dla postaci omawianej powieści wcale nie jest kresem zmagań z faszyzmem. Po 1945 roku księżna i jej przyjaciele angażują się w działalność polityczną mającą, z jednej strony, wzmocnić włoską lewicę, z drugiej zaś nie dopuścić do supremacji spadkobierców idei Benito Mussoliniego. Choć Modesta odżegnuje się od zinstytucjonalizowanej polityki i nie decyduje się kandydować do parlamentu, to odkrywa w sobie zamiłowanie do aktywizmu, zwłaszcza do przemawiania [Sapienza 2018: 538-539, $546,549,551]$ i oddolnej pracy z ludźmi ${ }^{47}$. Szybko jednak zniechęca się do tej działalności, zrażona zachowawczością i kompromiso-

Beatrice odnotowuje w pamiętniku następującą uwagę Modesty na temat spotkań socjalistów, w których obie uczestniczyły: „«Ech, Beatrice, tamten dom jest zupełnie jak kościół pełen fresków z madonnami i świętymi! Ale, jak mawiał Jacopo, z kościołów najlepiej uciec zaraz po tym, jak już się napatrzyło na te arcydzieła»" [Sapienza 2018: 188].

47 Odrzuciwszy propozycję kandydowania do parlamentu, bohaterka zapewniła: „[... ] będę pracować dla was, ale na dole, na placach, wśród tłumu, nie w jakimś pałacu, gdzie jest was dosyć, by nas bronić" [Sapienza 2018: 538]. 
wym nastawieniem lewicy [Sapienza 2018: 546-549] $]^{48}$. Bohaterka jest szczególnie rozczarowana postawą podporządkowujących się staremu ładowi polityczek. Wyraźnie widać to w jej przemyśleniach, ukazanych w świetnej scenie rozmowy z Joyce ${ }^{49}$, która po wojnie weszła w rolę prominentnej, zawodowej działaczki:

Strzeżcie się, Laleczko, Crispino, Olimpio, strzeżcie się! Za dwadzieścia, trzydzieści lat, kiedy będziecie płakać w jakiejś ciasnej klitce z dłońmi zmęczonymi wybielaczem, nie oskarżajcie mężczyzny. To nie mężczyzna was zdradził, ale tamte kobiety, dawniejsze niewolnice, które dobrowolnie zapomniały o swojej niewoli i wyrzekły się was, sięgając po władzę ramię w ramię z mężczyznami. [...]

W miejsce dłoni zżartych wybielaczem wam przeznaczono lata ponurego męskiego ćwiczenia w przywiązywaniu najbiedniejszych kobiet do taśmy produkcyjnej i okrutne bezsenne noce w imię wydajności za wszelką cenę. [Sapienza 2018: 547]

W przywołanym cytacie księżna nie tylko upomina się o sprawę kobiecą, piętnując pozorność postulatów emancypacyjnych głoszonych przez polityczki i polityków, lecz także przestrzega przed konsekwencjami kapitalistycznego porządku pracy, dzięki czemu jej wypowiedź zyskuje szerszy, uwzględniający różne uciśnione grupy, charakter.

Wydaje się, że próby jednoznacznego określenia światopoglądu głównej bohaterki Sztuki radości nie mają sensu, ponieważ nie jest to postać zamykająca się w jakichkolwiek konkretnych formułach. Na pewno jednak da się zauważyć sympatię Modesty - szczególnie przecież przywiązanej do niezależności - do lewicy wolnościowej, a zatem w dużym stopniu anarchistycznej (może nawet anar-

Przy okazji warto zaznaczyć, że o podobnej - przemijającej - fascynacji wzbudzaniem poruszenia wśród tłumów przez przemawianie pisała Goldman [2015: 43-44].

49 Dialog dotyczył artykułu, który księżna przygotowała do publikacji w czasopiśmie redagowanym przez swoją dawną przyjaciółkę. Tekst został odrzucony jako zbyt radykalny [Sapienza 2018: 546-549]. 
choindywidualistycznej). Jednocześnie (co zresztą wcale nie jest sprzeczne z przywołanym wyżej światopoglądem) postawa księżnej opiera się na, by posłużyć się określeniem zaczerpniętym z innego kontekstu, swoiście rozumianej pracy u podstaw, obejmującej nie tylko relacje z najbliższymi i działalność społeczną, lecz także budowanie własnej „sztuki radości”。

W tym miejscu należy również zapytać o stosunek powieści do feminizmu. Nie ulega wątpliwości, że kwestia kobieca zajmuje w utworze bardzo ważne miejsce ${ }^{51}$. Widzimy to choćby na przykładzie walki Modesty z krzywdzącymi stereotypami genderowymi. O przekonaniach dotyczących seksualności i cielesności była już mowa. W tym miejscu warto zaś wspomnieć o sprzeciwie bohaterki, wpisującym się zresztą także w kontekst refleksji anarchistycznej [por. Laskowski 2006: 465], wobec tradycyjnego modelu wychowania dziewcząt, wyrażanym zarówno w krytyce niektórych zachowań Beatrice [Sapienza 2018: 165, 172], jak i w strategiach wychowawczych stosowanych przez księżnę. Bohaterka sprzeciwia się bowiem odmiennym, krzywdzącym standardom edukacji dziewcząt i chłopców, piętnując zarazem udział kobiet w podtrzymywaniu tego porządku:

Oto jak to się zaczyna. Według nich pięcioletnia Laleczka już dziś powinna poruszać się inaczej, stać skromne, spuszczać oczka i budować w sobie jutrzejszą panienkę. Jak w klasztorze: prawa, zamknięcie, historia stworzona przez mężczyzn. Ale to kobieta zgodziła się trzymać klucze, zostać nieugiętą strażniczką mężczyzny. [Sapienza 2018: 310] $]^{\text {s2 }}$ zresztą kolejne elementy światopoglądu Modesty, które mogą się kojarzyć z Goldman [Laskowski 2015: 8-9].

51 Nie bez znaczenia pozostaje też to, że w tekście wielokrotnie przywoływana jest klasyczna dla lewicowej refleksji o emancypacji rozprawa Augusta Bebela Kobieta i socjalizm [Sapienza 2018: 111, 391, 507].

Warto dodać, że jeszcze innym elementem nowoczesnej wizji rodziny realizowanej przez Modestę jest nacisk na to, aby dzieci będące pod jej opieką same pracowały na swoje utrzymanie. Założenie to nie było przecież oczywiste w arystokratycznych kręgach na początku ubiegłego stulecia [Sapienza 2018: 158, 517]. 
Co więcej, m.in. w przytoczonych wcześniej rozważaniach Mody widzimy troskę bohaterki o losy kobiet w ogólności, jako grupy społecznej53. Wcześniej wspomniałam, że w utworze pojawiają się także inne kwestie podejmowane przez ruch feministyczny, np. problem aborcji. Jednocześnie w powieści unika się otwartego mówienia o feminizmie, co da się wytłumaczyć obawą narratorki przed stosowaniem ograniczających etykiet, a także, jak się wydaje, niechęcią do poglądów wprowadzających jakiekolwiek podziały między ludźmi, w tym - niszczących wspólnotę kobiet i mężczyzn ${ }^{54}$. Można zatem przypuszczać, że aby uniknąć wikłania się w terminologiczne spory, a zarazem nie umniejszać znaczenia

53 Podobne wątki Modesta przywołuje, krytykując stosunek Pranda do jego żony Amalii i, szerzej, utrzymujący się mimo pewnych zdobyczy emancypacji patriarchalny porządek rzeczywistości, wspierany także przez lewicowych działaczy: „I uważajcie, bo kiedy kobiety zorientują się, że wy, mężczyźni lewicy, uśmiechacie się z paternalistycznym pobłażaniem na to, co one mówią, kiedy twoja Amalia uświadomi sobie, że jej nie słuchasz i że wykańcza się na dwóch etatach: przy garach i w laboratorium - a właśnie, dlaczego nigdy mi nie mówisz o pracy Amalii, co? Dlaczego muszę słuchać wyłącznie o tym, że jest słodka, piękna albo zazdrosna? - więc kiedy się zorientują, to ich zemsta będzie straszna, Prando, jak w Ameryce" [Sapienza 2018: 557].

54 W taki sposób zapatrywała się na tę kwestię sama autorka, niezgadzająca się „na niezdrowy neofityzm podobny truciźnie (na pewno zaszczepionej przez władzę: skłócić mężczyznę z kobietą, by zniszczyć oboje [...]” [list Goliardy Sapienzy do Enza Siciliana; cyt. za: Scarpa 2018: 612-613]. Tę postawę pisarka kojarzyła przede wszystkim z narodzonym w Stanach Zjednoczonych feminizmem drugiej fali, przeciwstawionym pozytywnie ocenianym ruchom kobiecym z wcześniejszego okresu [list Goliardy Sapienzy do Enza Siciliana; cyt. za: Scarpa 2018: 612]. Zdaniem autorki krytykowany przez nią typ aktywizmu „zdradził sprawę kobiecą, bo zaczął naśladować mężczyzn i stał się emanacją kapitału, przemysłu i rynku" [Pellegrino 2018b: 637]. Wszystko to nie oznacza oczywiście, że książka Sapienzy nie może być odczytywana przy użyciu krytycznofeministycznych narzędzi [por. Bazzoni 2018; Kornacka 2018]. Na przykład zdaniem Serkowskiej [2019: 79] Sztuka radości to Bildungsroman „z typowymi dla powieści feministycznej przesunięciami akcentów”. Ciekawym, zaczerpniętym z popularyzatorskiego poziomu świadectwem tego rodzaju recepcji w Polsce jest również stanowisko Sylwi Chutnik i Karoliny Sulej. Autorki wpisują utwór w ramę feminizmu, wykorzystując m.in. metaforę siostrzeństwa $($ „[...] wspierajmy siostry z różnych części świata i epok" [Chutnik, Sulej 2018]). Podkreślają też inspirujący charakter Sztuki radości, wskazując na wspomniany już transformacyjny wymiar książki [Chutnik, Sulej 2018]. 
przedstawionych wyżej wątków, Sztukę radości najlepiej określić jako powieść zaangażowaną w sprawę kobiecą ${ }^{55}$.

Choć omawiane polskie utwory nie nawiązują bezpośrednio do działalności anarchistycznej, to podejmują temat zaangażowania politycznego. Co ważne, także z perspektywy wspomnianego nurtu, często chodzi o zaangażowanie oddolne. W tym kontekście warto przede wszystkim wspomnieć o Kronikach... Iwasiów. Jest to tekst znacznie mniej optymistyczny niż Sztuka radości, który jednak łączy z włoską książką zarówno - paradoksalnie - pewien dystans wobec politycznej aktywności, jak i przekonanie o potrzebie tego typu działalności. Jednocześnie, jak już wspomniałam, Małgorzata jest postacią o mniejszej energii niż Modesta, co przekłada się na jej ogólną nieufność do ludzi ${ }^{56}$. Oczywiście nie bez znaczenia pozostaje różnica czasu historycznego i przestrzeni między dwoma tekstami. O ile Sztuka radości mogła być zapisem porzuconej i odzyskanej na nowo, w prywatnym wymiarze, nadziei, o tyle Kroniki ... obrazują gasnący i ponownie rozbudzany entuzjazm, sinusoidę nastrojów towarzyszących aktywizmowi społecznemu i związane z nim wątpliwości ${ }^{57}$ [Iwasiów 2019: 41-42, 108-110, 317-321, 345-346]. Finał książki może jednak wskazywać, że to lęk i wściekłość, które Małgorzata w sobie gromadzi, kumulują wywrotowe, choć na razie nieukie-

Wydaje się, że formuła ta pasuje do na pozór paradoksalnego podejścia autorki, którą Francesca Todde określiła jako „antyfeministkę" i „wielbicielkę kobiet” [cyt. za: Murek 2018]. O powodach niechęci Sapienzy do feminizmu już pisałam. W tym miejscu wypada dodać, że pisarka była zafascynowana kobietami i silnie się z nimi utożsamiała, stale jednak kultywując wspólnotę z mężczyznami [Pellegrino 2018b: 656; Scarpa 2018: 612].

Częściowo ten stan rzeczy wnika z pracy bohaterki i poczucia, że jest prześladowana [Iwasiów 2019: 184-191, 243-248, 250-262]. Nie bez znaczenia pozostaje także wspomniana (i oddziałująca na Małgorzatę) niestabilność psychiczna jej matki [Iwasiów 2019: 74-87, 102-107, 227-236].

57 Por. „Na panele i wieczorki ludzie przychodzą, przyjęły się jako forma szlachetnego uczestnictwa w pożytecznych inicjatywach, które nie wychodzą poza fazę postulatywną" [Iwasiów 2019: 42]. Albo: „-Nie byłoby dla ciebie ciekawe zbliżyć się do wstępującego pokolenia? W sumie dają ci szansę - wtrąciła Basia. [...] Szansa, w Wytwórni sądziłyśmy, że zmieniamy świat, a teraz mowa jest o szansie" [Iwasiów 2019: 319]. Przytoczone cytaty pokazują rozczarowanie, konieczność ograniczania się do półśrodków, które mimo wszystko ciągle współistnieją z potrzebą zaangażowania. 
runkowane emocje („Złość we mnie przestaje nabrzmiewać, jest w sam raz, podrośnięta i twarda, gotowa do użycia. Jeszcze nie wiem czym, ale na pewno wystrzeli” [Iwasiów 2019: 378] $]^{58}$ ). W podobny sposób - jako coś usytuowanego między nadzieją i rewoltą ${ }^{59}$ a sceptycyzmem i ironią $^{60}-\mathrm{w}$ powieści przedstawia się zaangażowanie feministyczne ${ }^{61}$. Subtelnie do tej perspektywy Iwasiów odniosła się także w utworze $W$ powietrzu, w którym narratorka i bohaterka przedstawia losy założonego przez siebie pisma literackiego. Nie był to wprawdzie magazyn feministyczny, ale w upodobaniach redaktorek dało się zauważyć niechęć do literatury opartej na męskiej perspektywie i preferowanie twórczości kobiet ${ }^{62}$. Z kolei choć w powieści Zientek nie mówi się bezpośrednio o feminizmie, to w tekście pojawia się wiele odniesień do zagadnień dyskutowanych przez ten ruch (i, szerzej, podejmowanych w obrębie refleksji na temat płci i seksualności). Utwór podejmuje przecież na swój sposób temat kobiecego wyzwolenia - na płaszczyźnie społecznej i erotycznej, mówi o tabuizowanych sferach kobiecości (zwłasz-

58 Jak się wydaje, w zacytowanym fragmencie Iwasiów wskazuje też na ambiwalencję społecznego gniewu, który przecież - źle zagospodarowany - może zostać wykorzystany w niehumanitarny sposób, np. przez przemocowe ideologie.

59 Por. np. „Marksizmem pachnie ta przemowa [... ], co mi tak bardzo nie przeszkadza, póki rymuje się z feminizmem" [Iwasiów 2019: 320].

Ironicznie wydają się brzmieć np. słowa Małgorzaty opisujące jej związek z Anną: „Należymy do po tego samego Kościoła Kobiet. Postępowego, otwartego, ceniącego więzi. A przynależność nam wystarczy” [Iwasiów 2019: 273 (por. też np. nieco parodystyczny feministyczny manifest Iwasiów [2019: 291-292]).

61 Napięcie między nadzieją a sceptycyzmem najlepiej oddają opisy spotkań grupy kobiet, w której działała bohaterka. Z jednej strony rozmowy odkrywały wspólnotę bolesnych kobiecych doświadczeń i dawały poczucie sily, z drugiej jednak zapał uczestniczek nieuchronnie wygasał [Iwasiów 2019: 291-305].

62 Na takie założenia może wskazywać poniższy fragment: „Chłopcy też przychodzili, ale dość szybko odkryłam, że nie muszę czytać wierszy o snuciu się i prozy o snuciu się oraz podbojach miłosnych, a także o wywołującym snucie piciu whisky i paleniu marihuany. Nie bardzo wchodziły mi również teksty o ojcach pijakach oraz o niewiernych kobietach. Wejrzawszy w siebie, stwierdziłam, że nie biorą mnie wszystkie te ujęte retrospektywnie tematy - ojcowie, młode kochanki, snucie się i picie, muzyka, przygody w wielkim mieście i powroty na prowincję - mające w tle teksty poprzedników, którzy również pisali o polskości i ją dekonstruowali, niezupełnie zarzucali pytania metafizyczne i balansowali między odpowiedzialnością a jej brakiem, co zawsze prowadziło ich do snucia się i picia, a także do ogólnego i szczególnego pieprzenia się" [Iwasiów 2014: 156]. 
cza o życiu erotycznym, choć także o starzeniu się $\left.e^{63}\right)$ i zahacza o problematykę nienormatywnej tożsamości oraz nieoczywistości genderowej identyfikacji ${ }^{64}$.

Co zatem Sztuka radości może dać polskiej literaturze? Przede wszystkim powieść wchodzi w dialog z innymi utworami zaangażowanymi w sprawę kobiet. Natomiast anarchistyczne zaplecze włoskiego tekstu dotyka pewnego marginesu polskiej kultury. Jest to jednak margines - by luźno nawiązać do znanej koncepcji bell hooks [2008] - produktywny, subwersywny i, dodajmy, od dawna obecny, przez co ma szansę stać się inspirujący ${ }^{65}$. W niniejszym artykule zależało mi na przyjrzeniu się transformacyjnemu wymiarowi książki Sapienzy (budowanemu m.in. przez kwestie omówione wyżej) i usytuowaniu jej w kontekście współczesnej polskiej literatury. Co z tym bogactwem zrobią odbiorczynie/odbiorcy, w tym

63 Choć Ewa dopiero ukończyła czterdzieści lat i nadal jest atrakcyjną osobą w pełni sil, to zaczyna się mierzyć z kulturowymi stereotypami na temat starości kobiet, przede wszystkim z przekonaniem, że to stan, którego należy się wstydzić i którego skutki trzeba tuszować [Zientek 2016: 53-54, 114-117]. W tym miejscu warto dodać, iż Modesta nie podporządkowała się tego rodzaju presji. Nie chciała wpisać się w rolę statecznej matrony, a zarazem odważnie czerpała radość i rozkosz z upływu lat, będącego dla niej źródłem nie słabości i starzenia się, lecz dojrzałości [Sapienza 2018: 315, 550-551, 554, 559-561, 592-593]. Buntując się przeciwko oczekiwaniom Pranda, Modesta zwraca uwagę na manipulacje, jakim w dyskursie podlega wiek senioralny. Przy okazji po raz kolejny krytykuje skostniałe formy życia rodzinnego: „[...] nie możesz teraz przekreślić tamtego działania bez reszty podporządkowując się [...] lękowi przed starością, który ci wszczepiono, by nie burzyć porządku społecznego, by nie uszkodzić tej fortecy, którą - faszyzm czy nie faszyzm - zawsze jest rodzina, poligon przyszłych żołnierzy, matek-żołnierzy, babek-królowych. [...] Również słowo «starość» kłamie, Modesto, upchano w nie przerażające zjawy, tak jak w słowo «śmierć», żebyś była spokojna i potulna i nie kwestionowała ustanowionych praw. Kto wie, czym jest starość? Kiedy się zaczyna?" [Sapienza 20018: 559]. Ironicznie do oczekiwań wobec starzenia się kobiet odnosi się również Iwasiów [2006: 156-168, zwłaszcza 163-164] w opowiadaniu Testament ze zbioru Smaki i dotyki.

64 Warto np. zwrócić uwagę na fragment, w którym Ewa, pod wpływem rozważań o Komornickiej/Właście, zastanawia się, na jakiej podstawie uznała mijaną na ulicy starszą osobę za kobietę [Zientek 2016: 96- 97].

65 Już po napisaniu pierwszej wersji tego artykułu anarchizm, także w połączeniu z praktyką queerową, zaczął odgrywać w polskim życiu społecznym, politycznym i kulturowym coraz większą rolę. Przyszłość pokaże, czy ostatnie wydarzenia, związane m.in. z głośną sprawą Margot z kolektywu Stop Bzdurom oraz protestami dotyczącymi zakazu aborcji, znajdą oddźwięk w rodzimej literaturze. 
pisarze i pisarki, pozostaje sprawą otwartą. Z pewnością jednak istnieje wiele linii włączania Sztuki radości w rodzimą twórczość, a ten szkic wskazał zaledwie część z nich.

\section{Bibliografia}

Antonów Radosław (2004), Pod czarnym sztandarem. Anarchizm w Polsce po 1980 roku, Wydawnictwo Uniwersytetu Wrocławskiego, Wrocław.

Bazzoni Alberica (2018), Writing for Freedom. Body, Identity and Power in Goliarda Sapienza's Narrative, Peter Lang, Berno.

Beauvoir Simone de (2003), Druga pteć, przeł. Gabriela Mycielska i Maria Leśniewska, Jacek Santorski \& Co, Warszawa.

bell hooks (2008), Margines jako miejsce radykalnego otwarcia, przel. Ewa Domańska, „Literatura na Świecie”, nr 1-2, s. 108-117.

Butler Judith (2008), Uwikłani w płeć, przeł. Karolina Krasuska, Wydawnictwo Krytyki Politycznej, Warszawa.

Castagné Nathalie (2019), Goliarda Sapienza ou l'art de la joie. Épisode 1: Vie de Goliarda Sapienza, wywiad przepr. Matthieu GarrigouLagrange, „La compagnie des auteurs”, 3 kwietnia [dostęp: 11 czerwca 2020], https://tinyurl.com/ya7cdugx.

Chutnik Sylwia (2016), Emma Goldman i anarchofeministki w Polsce, czyli taniec przybliza do rewolucji, „Our Europe. Entography - Ethnology Anthroplogy of Culture", nr 5, s. 41-50.

Chutnik Sylwia, Sulej Karolina (2018), „Barłóg Literacki”, 16 listopada, [dostęp: 3 maja 2020], https://tinyurl.com/y8p6rvda.

Goldman Emma (2015), Anarchizm i inne eseje, przeł. i red. Jagoda

Dolińska, Andrzej Grzybowski, Piotr Laskowski i in., Oficyna Bractwa „Trojka”, Poznań.

Ilnicka Voca (2020), Uniesienie spódnicy. Seksualne doświadczenia i kobieca moc, [wydawca nieznany], Wrocław.

Iwasiów Inga (2006), Smaki i dotyki, Świat Książki, Warszawa. Iwasiów Inga (2012), Na krótko, Wielka Litera, Warszawa. Iwasiów Inga (2014), W powietrzu, Wielka Litera, Warszawa. Iwasiów Inga (2019), Kroniki oporu i miłości, Świat Książki, Warszawa. Kamiński Antoni A. (2011), Polskie badania nad anarchizmem.

Przegląd literatury, w: Studia z dziejów polskiego anarchizmu, red. Eryk Krasucki, Michał Przyborowski, Radosław Skrycki, Szczecińskie Towarzystwo Naukowe, Instytut Historii i Stosunków Międzynarodowych Uniwersytetu Szczecińskiego, Szczecin, s. 296-346. 
Kornacka Barbara (2018), Miłość a wolność. Miłość według Goliardy Sapienzy: „L'arte della gioia”, „Acta Philologica”, nr 52, s. 145-154.

Kwiecień Tomasz (2018), Od tłumacza, w: Goliarda Sapienza, Sztuka radości, przeł. Tomasz Kwiecień, Wydawnictwo Kobiece, Białystok, s. 5-6.

Laskowski Piotr (2006), Szkice z dziejów anarchizmu, Muza SA, Warszawa.

Laskowski Piotr (2015), Wstęp, w: Emma Goldman, Anarchizm i inne eseje, przeł. i red. Jagoda Dolińska, Andrzej Grzybowski, Piotr Laskowski i in., Oficyna Bractwa „Trojka”, Poznań, s. 5-11.

Laskowski Piotr (2019), Wprowadzenie, w: Maria Orsetti, Kooperatyzm, anarchizm, feminizm. Wybór pism, wybór, oprac. i red. nauk. Piotr Laskowski, Oficyna Naukowa, Warszawa, s. XI-LXXVII.

Majewska Ewa (2014), Nurty feminizmu, w: Encyklopedia gender. Płeć w kulturze, red. Monika Rudaś-Grodzka, Katarzyna NadanaSokołowska, Agnieszka Mrozik i in., Czarna Owca, Warszawa, s. 351-354.

Murek Weronika (2018), Zostawita aktorstwo dla pisania, ale jej debiut byt dla wydawców zbyt śmialy. Dziś powieść Goliardy Sapienzy uznawana jest za arcydzieło, „Książki. Magazyn do czytania” dodatek do: „Gazeta Wyborcza”, nr 5/32, [dostęp: 3 maja 2020], https://tinyurl. com/yb54elje.

Navarre Julie, Navarre Jean-Philippe (2018), Goliarda Sapienza (1924-1996): la Madone indocile, „Une vie, une œuvre”, 14 kwietnia, [dostęp: 11 czerwca 2020] https://tinyurl.com/y8h4cfr5.

Pellegrino Angelo (2018a), Długa droga „Sztuki radości”, w: Goliarda Sapienza, Sztuka radości, przeł. Tomasz Kwiecień, Wydawnictwo Kobiece, Białystok, s. 7-13.

Pellegrino Angelo (2018b), Portret Goliardy Sapienzy, w: Goliarda Sapienza, Sztuka radości, przeł. Tomasz Kwiecień, Wydawnictwo Kobiece, Białystok, s. 625-657.

Rappaport Herman, zebrał i oprac. (1981), Anarchizm i anarchiści na ziemiach polskich do 1914 roku, PWN, Warszawa.

Rubik Anja (2018), \#SEXEDPL. Rozmowy Anji Rubik o dojrzewaniu, miłości i seksie, W.A.B., Warszawa.

Sapienza Goliarda (2018), Sztuka radości, przeł. Tomasz Kwiecień, Wydawnictwo Kobiece, Białystok.

Scarpa Domenico (2018), Nie zmieniając niczego, w: Goliarda Sapienza, Sztuka radości, przel. Tomasz Kwiecień, Wydawnictwo Kobiece, Białystok, s. 595-623.

Serkowska Hanna (2019), Habent sua fata libelli, „Nowe Książki”, nr 2, s. 78-79. 
Sexed.pl (2020), [dostęp: 11 czerwca 2020], https://sexed.pl/. Wisłocka Michalina (1978), Sztuka kochania, Iskry, Warszawa. Wyka Kazimierz (2003), Młoda Polska, t. 1: Modernizm polski,

Wydawnictwo Literackie, Kraków.

Zientek Sylwia (2016), Podróż w stronę czerwieni, Muza SA, Warszawa.

\section{Katarzyna Lisowska}

\section{The Art of Joy and the Practice of Anarchy. On Goliarda Sapienza's}

\section{Novel and a Few Polish Texts}

The article discusses the Polish translation (2018) of Goliarda Sapienza's novel L'arte della gioia (The Art of Joy, in Polish Sztuka radości, trans. by Tomasz Kwiecień) in relation to the selected works of Inga Iwasiów and Sylwia Zientek. Anarchism, which provides the ideological background of the Italian book, serves as the basic point of reference for this interpretation. The author points to the issues from Sapienza's novel which are important from the perspective of anarchism and which can also be found in the Polish texts mentioned in the article. The aim of this analysis is to discuss the context in which The Art of Joy functions in Poland and to suggest the possible lines of interpretation that can be drawn between this novel and contemporary Polish literature.

Keywords: women's literature; anarchism; corporeality; sexuality; family; politics.

Katarzyna Lisowska - pracuje w Zakładzie Teorii Literatury w Instytucie Filologii Polskiej na Uniwersytecie Wrocławskim. Interesuje się szeroko rozumianym dyskursem genderowym, a także literackimi reprezentacjami głodu, starości i cierpiącego ciała oraz anarchizmu. Opublikowała książkę Metaforyczność w dyskursie genderowym polskiego literaturoznawstwa po 1989 roku (2019).Adres e-mail: katarzyna.lisowska@uwr.edu.pl. 